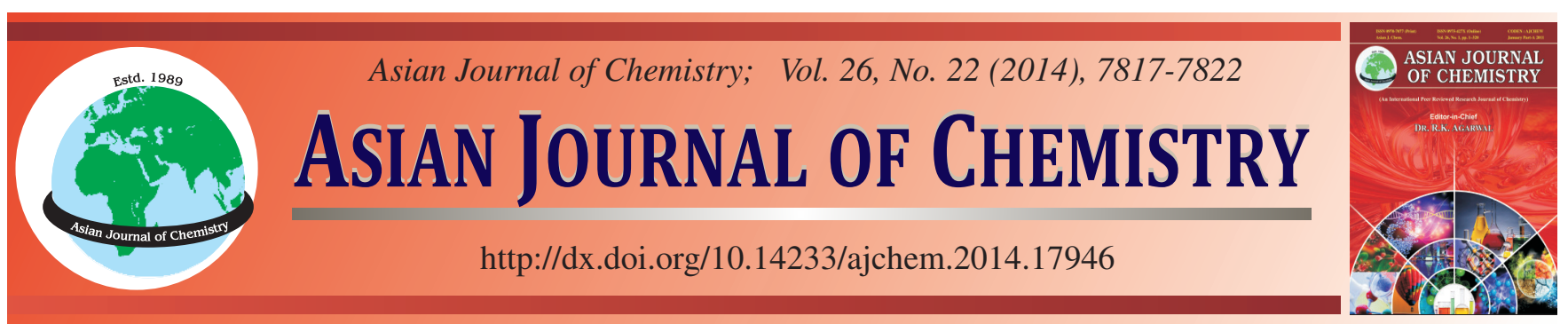

\title{
Stress Degradation Studies and HPLC Method Development for Simultaneous Estimation of Prednisolone Acetate and Chloramphenicol in Topical Eye Drops
}

\author{
M. Ahsan Hafiz ${ }^{1, *}$, Muhammad Idrees ${ }^{2}$, Imran Tariq ${ }^{1}$, Sohail Amjad ${ }^{1}$ and Arshad Ali Shah ${ }^{3}$
}

${ }^{1}$ University College of Pharmacy, University of the Punjab, Lahore-54000, Pakistan

${ }^{2}$ Department of Chemistry, Government College University, Lahore, Pakistan

${ }^{3}$ Department of Pharmacy, University of South Asia, Lahore, Pakistan

*Corresponding author: Tel: +92 333 4060054; E-mail: ahsanshareef105@ hotmail.com

\begin{abstract}
A rapid reversed phase liquid chromatographic method was developed and validated for simultaneous HPLC determination of chloramphenicol and prednisolone acetate. The proposed method was effectively applied on separation of chloramphenicol and prednisolone acetate in the presence of excipients and degradation products in eye drops. Chromatographic separation was achieved using combination of ammonium acetate buffer $(0.02 \mathrm{M} ; \mathrm{pH} 4)$ and methanol $(30: 70 \mathrm{v} / \mathrm{v})$ at a flow rate of $1.5 \mathrm{~mL} / \mathrm{min}$. The effluent from column was monitored at 276 and $245 \mathrm{~nm}$ for chloramphenicol and prednisolone acetate, respectively. A good linear relationship was observed over the concentration ranges $0.0256-80$ and $0.064-200 \mu \mathrm{g} / \mathrm{mL}$ with correlation coefficient 0.9999 and 0.9999 for chloramphenicol and prednisolone acetate, respectively. Calculated LOQ were $36 \mathrm{ng} / \mathrm{mL}$ for chloramphenicol and $31 \mathrm{ng} / \mathrm{mL}$ for prednisolone acetate. Active ingredients (chloramphenicol and prednisolone acetate) and degradation products were resolved in less than 4 min. The developed method was validated according to ICH guidelines.
\end{abstract}

Keywords: Reversed phase, Degradation products, Chloramphenicol, Prednisolone acetate.

\section{INTRODUCTION}

Corticosteroids have been widely used as antiinflammatory agents in medicine. Now a days, antibacterials are frequently combined with corticosteroids in pharmaceuticals since corticosteroids are meant to treat inflammation, they may cause temporary masking of the underlying disease e.g., infection. Therefore, combination of steroid with antibiotic is useful to resolve both inflammation and infection ${ }^{1}$.

Prednisolone acetate, $11 \beta$ 17, 21-trihydroxypregna-1,4diene-3,20-dione 21-acetate (Fig. 1), is a corticosteroid used to treat steroid-responsive inflammatory ocular conditions where ocular bacterial infection or a risk of infection exists ${ }^{2}$. It is differentiated from dexamethasone due to its higher corneal permeability, although its glucocorticoid potency and receptor binding capacity are smaller ${ }^{3}$. It has been quantitated in multicomponent mixtures of natural and synthetic corticosteroids ${ }^{4}$ or as adulterant ${ }^{5}$ in local drugs by HPLC. Chloramphenicol (Fig. 2) is a broad spectrum antibiotic possessing antibacterial activity against Gram positive and Gram negative bacterial infections, used for the treatment of rickettsial and chlamydial diseases and topically for superficial conjunctival infections. The drug acts by binding to 50S subunit in the prokaryotic<smiles>CC12C=CC(=O)C=C1CC[C@H]1[C@@H]2CC[C@]1(O)C(=O)CO</smiles>

Fig. 1. Chemical structure of prednisolone<smiles>O=C(NC(CO)[C@H](O)c1ccc([N+](=O)[O-])cc1)C(Cl)Cl</smiles>

Fig. 2. Chemical structure of chloramphenicol

cell and thus inhibiting protein synthesis ${ }^{6-8}$. Prednisolone in conjunction with chloramphenicol is used to cure acute and subacute conjunctivitis. The combination is effective against the following aerobic gram positive and negative bacteria such as $S$. aureus, $S$. epidermidis, $S$. pneumonia and haemophilus influenza ${ }^{9}$. 
Literature survey revealed different HPLC methods for concurrent determinations of prednisolone acetate and chloramphenicol in topical formulations. Hongxin ${ }^{10}$ described HPLC method for concurrent determination of prednisolone acetate and chloramphenicol in eye drops. Katakam and Sireesha ${ }^{11}$ developed another HPLC method for simultaneous determination of prednisolone acetate and chloramphenicol in formulations. When these methods were applied to characterize compounds in eye drops of different companies while maintaining the same chromatographic conditions, the methods did not reproduce results as desired. This might be due to the fact that the already developed methods did not confirm robustness of the processes. Method developed by Katakam and Sireesha applied stress testing to individual components separately rather than combined eye drops samples. So there was a need to develop an alternative fast and accurate method involving simultaneous analysis of prednisolone acetate and chloramphenicol in eye drops through HPLC.

The present study with a unique mobile phase composition reports a simple HPLC method for the simultaneous determination of prednisolone acetate and chloramphenicol in the presence of degraded products formed under applied stress conditions. Stress of different types was applied directly to sample solutions. Attempts were made to minimize the analysis time and cost of analysis by optimization of chromatographic conditions. The degraded products demonstrated no interferences with the active drug ingredients measurement. Stress testing provides evidence about the quality of a drug substance under the influence of various factors (acid, base, heat and humidity etc.) and aids in establishing shelf life for the drug ${ }^{7}$.

\section{EXPERIMENTAL}

Prednisolone acetate was provided as gift sample from Schazoo pharmaceuticals Ltd., Lahore and chloramphenicol was procured from Allergan Pharma, Lahore. HPLC grade methanol was purchased from Sigma Aldrich, USA. Double distilled water was used during the study. The pharmaceutical eye drops containing $1 \%$ prednisolone acetate and $0.4 \%$ chloramphenicol were Prednisynth (Schazoo Laboratories, Lahore), Prednicol (Remington Pharmaceuticals, Lahore) and Predni-C (Mediceena Pharmaceuticals, Lahore) were purchased from market. Ammonium acetate, phosphoric acid, sodium hydroxide and potassium permanganate were sourced from Merck chemicals, USA and were of analytical grade.

Instrumentation and chromatographic conditions: Chromatography was performed with Shimadzu LC 20 AT HPLC system comprising pump, column compartment, UV detector (SPD-M20A) and ultrasonic bath. The system was integrated with LC solutions software. Compounds were separated on Thermo Hypercil C-18 column $(250 \times 4.6,5 \mu \mathrm{m}$, Runcorn, UK) and elution of components was made by reversed phase mode. The mobile phase was a 70:30 (v/v) mixture of methanol and $0.02 \mathrm{M}$ ammonium acetate buffer $(\mathrm{pH} 4)$ and passed through column at a flow rate of $1.5 \mathrm{~mL} / \mathrm{min}$. Before passing through the HPLC system, mobile phase was filtered through $0.45 \mu$ nylon filter and degassed in a sonicator (PS, 02000A). The injection volume was $20 \mu \mathrm{L}$ using rheodyne injector and detection was made by ultraviolet (UV) absorption at 276 and $245 \mathrm{~nm}$ for chloramphenicol and prednisolone acetate, respectively. Chromatographic separation was performed at room temperature $\left(25-30^{\circ} \mathrm{C}\right)$.

Preparation of stock solution: The stock solution of chloramphenicol and prednisolone acetate $(0.4 \mathrm{mg} / \mathrm{mL}$ and 1 $\mathrm{mg} / \mathrm{mL}$, respectively) was prepared by dissolving $10 \mathrm{mg}$ of chloramphenicol and $25 \mathrm{mg}$ prednisolone acetate to a small amount of mobile phase in a $25 \mathrm{~mL}$ volumetric flask and then raising the volume up to the mark with mobile phase.

Preparation of working standard solution: $5 \mathrm{~mL}$ of standard stock solution was taken accurately in $25 \mathrm{~mL}$ volumetric flask. $10 \mathrm{~mL}$ of mobile phase was added, mixed and made up to volume. The concentration of working standard solution is 80 and $200 \mu \mathrm{g} / \mathrm{mL}$ for chloramphenicol and prednisolone acetate, respectively.

Preparation of sample (eye drops) solution: Sample solution was prepared by mixing three eye drops of each company. Accurately $1 \mathrm{~mL}$ of opthalmic solution was taken and diluted to $25 \mathrm{~mL}$ using mobile phase. The solution was sonicated for $10 \mathrm{~min}$. The concentrations of final sample solutions for chloramphenicol and prednisolone acetate were 80 and $200 \mu \mathrm{g} / \mathrm{mL}$, respectively.

Linearity: Linearity of the developed method was done by analyzing six solutions in the range of $0.0256-80 \mu \mathrm{g} / \mathrm{mL}$ $(0.0256,0.128,0.64,3.2,16$ and $80 \mu \mathrm{g} / \mathrm{mL})$ for chloramphenicol and $0.064-200 \mu \mathrm{g} / \mathrm{mL}(0.064,0.32,1.6,8,40$ and $200 \mu \mathrm{g} / \mathrm{mL}$ ) for prednisolone acetate.

Specificity (forced degradation studies): Assay of the active drug and the degradation products generated during stability studies are the two major determinants of shelf life of a drug product. Therefore, degradation studies were conducted to evaluate the stability of the products as well as to assess the specificity of the method. Four types of degradation studies i.e., acidic, basic, oxidative and thermal were performed.

Acid degradation studies: For this purpose, $5 \mathrm{~mL}$ of standard stock solution was added to $25 \mathrm{~mL}$ volumetric flask. Then, $0.1 \mathrm{~mL}$ of $2 \mathrm{~N} \mathrm{HCl}$ was added and kept at room temperature for $20 \mathrm{~min}$. After completion of the stress, the solution was neutralized with $1.25 \mathrm{~N} \mathrm{NaOH}$ and was finally diluted up to $25 \mathrm{~mL}$ with mobile phase.

Basic degradation studies: These studies were carried out at normal conditions of humidity and temperature using $1.25 \mathrm{~N} \mathrm{NaOH}$. For this purpose, $5 \mathrm{~mL}$ of standard stock solution was added to $25 \mathrm{~mL}$ volumetric flask. $0.06 \mathrm{~mL}$ of $1.25 \mathrm{~N}$ $\mathrm{NaOH}$ was added and kept for $20 \mathrm{~min}$. Then, the solution was neutralized with $2 \mathrm{~N} \mathrm{HCl}$ solution and was finally diluted up to $25 \mathrm{~mL}$ with mobile phase.

Oxidative degradation studies: For performing oxidative stress studies, $5 \mathrm{~mL}$ of standard stock solution was added to $25 \mathrm{~mL}$ volumetric flask. $0.5 \mathrm{~mL}$ of $0.006 \mathrm{KMnO}_{4}$ was added and kept for $30 \mathrm{~min}$. Finally, it was diluted to $25 \mathrm{~mL}$ with mobile phase.

Thermal degradation studies: For these studies, $5 \mathrm{~mL}$ standrad stock soultion was added to $25 \mathrm{~mL}$ round bottom flask equipped with reflux condenser. The solution was undergone reflux for $2 \mathrm{~h}$ at $120{ }^{\circ} \mathrm{C}$. Then, it was cooled at room temperature and volume was made up to $25 \mathrm{~mL}$ with mobile phase. 
Precision: The intra-day precision was demonstrated in terms of $\%$ RSD of three different concentrations as used for recovery study by injecting 6 replicate injections of each concentration in same day. The inter day variability was examined for the same solution by injecting 18 replicates in 3 days.

Limits of detection and quantitation: The limit of detection (LOD) and limit of quantitation (LOQ) of the method were calculated on the basis of standard deviation of the response and slope ${ }^{12}$ by applying following formula.

$$
\begin{gathered}
\text { Limit of detection }=3.3 \mathrm{\sigma} / \mathrm{S} \\
\text { Limit of quantitation }=10 \mathrm{\sigma} / \mathrm{S}
\end{gathered}
$$

where $\sigma$ is standard deviation of response and $s$ is the slope of the calibration curve. Six replicate injections of mobile phase were injected to calculate standard deviation of response.

\section{RESULTS AND DISCUSSION}

Optimization of chromatographic conditions: A number of preliminary experiments were performed to resolve chloramphenicol, prednisolone acetate, excipients and degradation products. Method development was started using $0.02 \mathrm{M}$ ammonium acetate buffer $\mathrm{pH} 4$ and acetonitrile in the ratio of 40:60, 30:70, 35:65 (v/v) for simultaneous determination of chloramphenicol and prednisolone acetate using hypercil C-18 column. By applying these compositions of mobile phase, both chloramphenicol and prednisolone acetate were not resolved in terms of tailing. Then acetonitrile was replaced with methanol and monolithic column was used for better elution but remained unsuccessful. Same composition of mobile phase was tried on Thermo Hypersil C-18 $(250 \times 4.6 \mathrm{~mm}, 5 \mu \mathrm{m}$, Runcorr., U.K) column, very sharp peaks of chloramphenicol and prednisolone acetate were obtained. Subsequently, composition of methanol was adjusted to obtain better resolution of chloramphenicol, prednisolone acetate, excipients and degradation products. Upon application of the proposed method, well separated sharp peaks were obtained for both chloramphenicol and prednisolone acetate at retention times of 2.269 and 3.659 , respectively. The representative chromatogram of chloramphenicol and prednisolone acetate were given in Fig. 3. The developed chromatographic method was validated in accordance with ICH guidelines ${ }^{13}$.

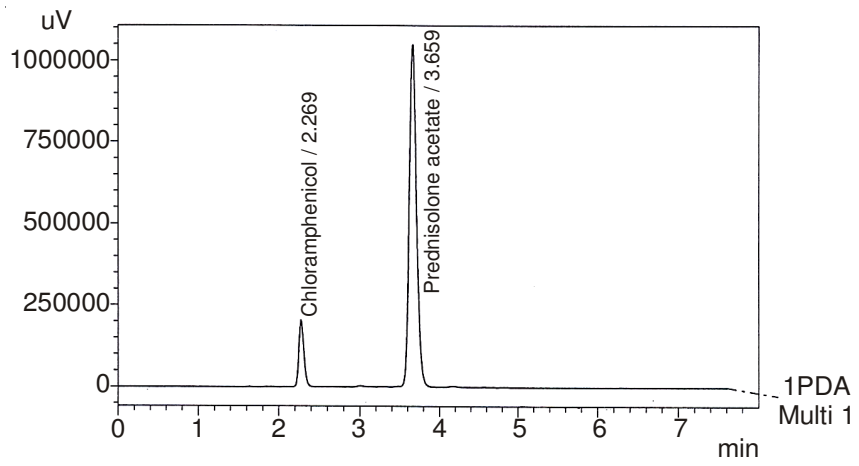

Fig. 3. Typical chromatogram showing peaks of chloramphenicol and prednisolone acetate

Method validation: Validaton parameters performed include specificity, linearity, limit of detection and quantitation, accuracy and precision.
Specificity: Forced degradation studies were performed to establish the specificity. To perform this test $5 \mathrm{~mL}$ of the stock solution was treated with $100 \mu \mathrm{L} \mathrm{HCL} \mathrm{(2M)} \mathrm{for} 20 \mathrm{~min}$, $60 \mu \mathrm{L} \mathrm{NaOH}(1.25 \mathrm{~m})$ for $20 \mathrm{~min}, 500 \mu \mathrm{L} \mathrm{KMNO}_{4}(0.006 \mathrm{M})$ for $30 \mathrm{~min}$, heat at $120^{\circ} \mathrm{C}$ and reflux for $2 \mathrm{~h}$. All the solutions were diluted with mobile phase to a theoretical concentration of 60 and $200 \mu \mathrm{g} / \mathrm{mL}$ for chloramphenicol and prednisolone acetate respectively. Acidic and alkaline samples were neutralized prior to final dilution. The representative chromatograms of acidic, basic, oxidative and thermal stress tests for chloramphenicol and prednisolone acetate were given in Figs. 4-8, respectively.

Linearity of the method: Linearity of the developed method was done by analyzing six solutions in the range of

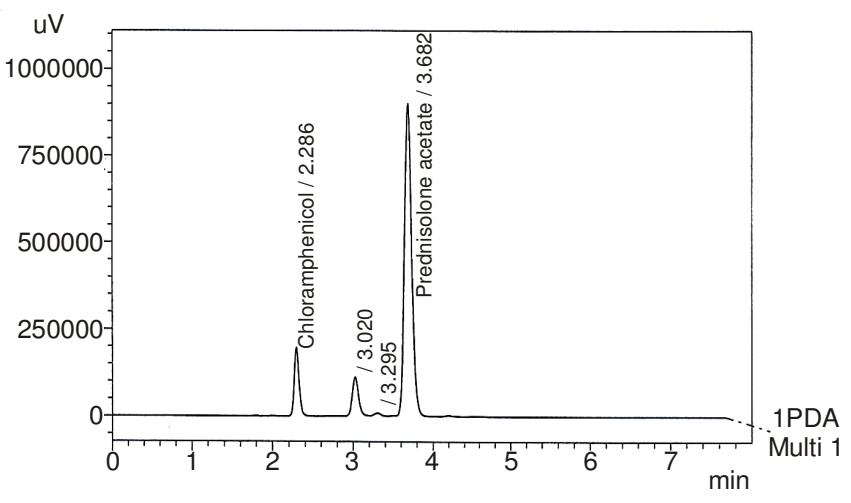

Fig 4: Acid stress treated sample analytes

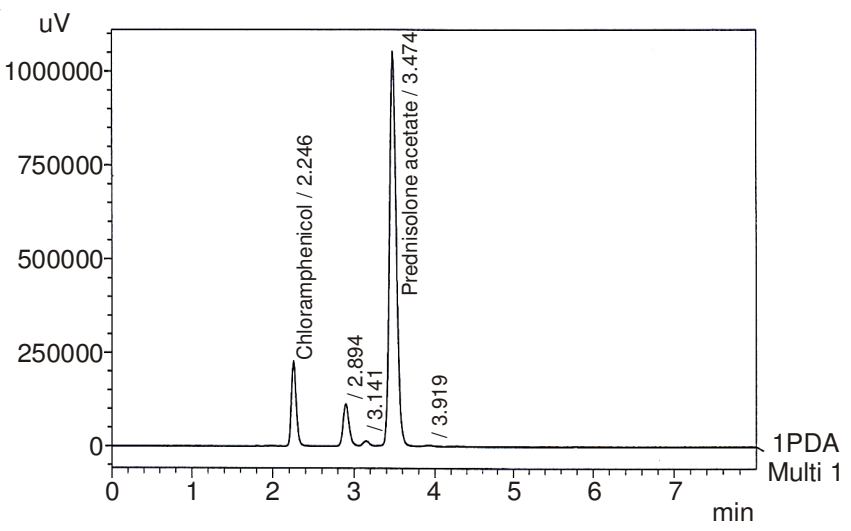

Fig. 5. Chromatogram showing basic stress

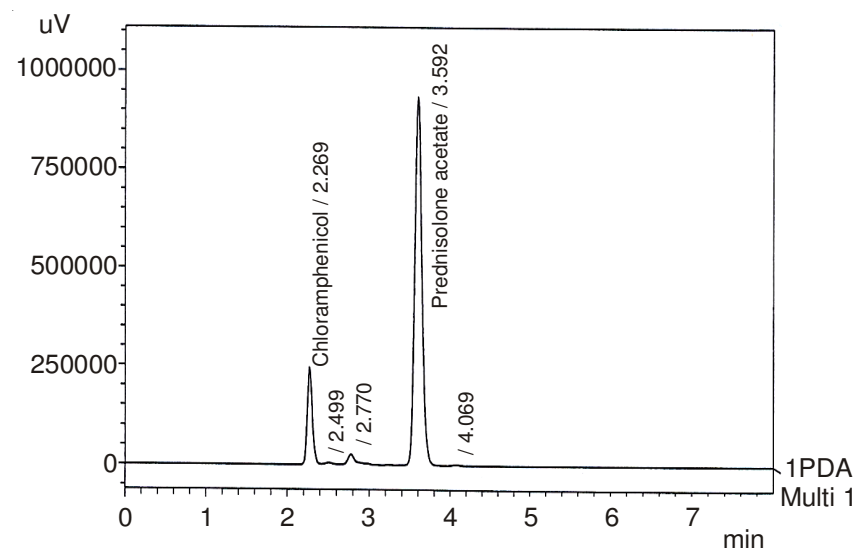

Fig. 6. Oxidative stress based degradation 


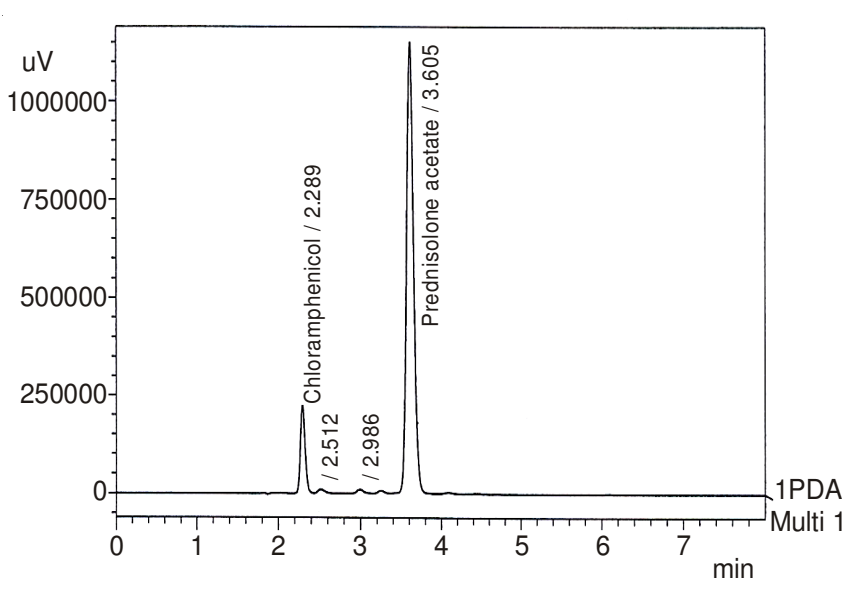

Fig. 7. Chromatogram showing heat induced degradation

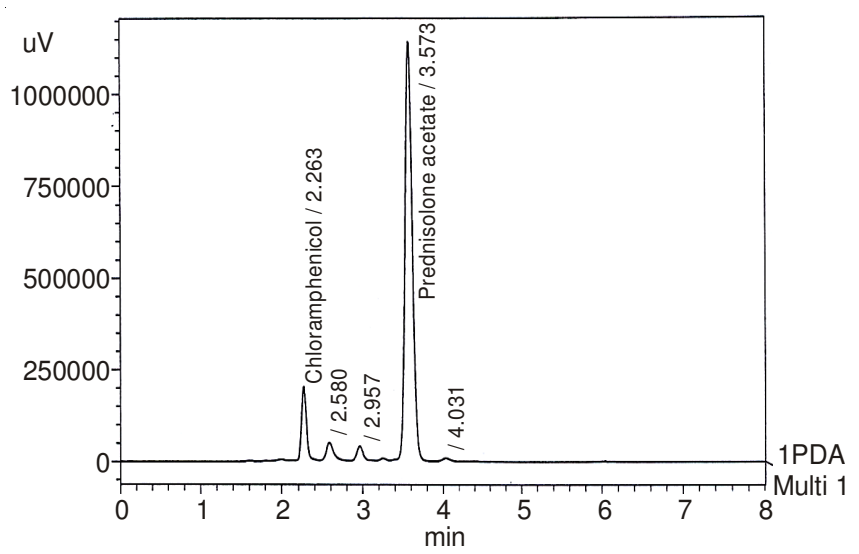

Fig. 8. Chromatogram of sample eye drops (Prednisynth) in the presence of excipients

$0.00256-80 \mu \mathrm{g} / \mathrm{mL}(0.0256,0.128,0.64,3.2,16$ and $80 \mu \mathrm{g} / \mathrm{mL})$ for chloramphenicol and $0.064-200 \mu \mathrm{g} / \mathrm{mL}(0.064,0.32,1.6$, 8,40 and $200 \mu \mathrm{g} / \mathrm{mL}$ ) for prednisolone acetate. Each concentration was analyzed in triplicate. The peak areas obtained against each concentration of the analytes were used to build a linear regression equation and to determine value of correlation coefficient. Good linearity was observed for chloramphenicol over the range of $0.0256-80 \mu \mathrm{g} / \mathrm{mL}$ with regression line equation $=31273 \mathrm{x}+267.6$ and correlation coefficient was found to be 0.9999 . For prednisolone acetate, the linearity was found over the range of $0.064-200 \mu \mathrm{g} / \mathrm{mL}$ with linear regression equation and correlation coefficient were calculated to be 35009x +1843.9 and 0.9999 , respectively. Linearity graph for chloramphenicol and prednisolone acetate are given in Figs. 9 and 10 , respectively.

Limit of detection and quantitation: Quantitation is the lowest amount of the analyte which can be quantitatively determined with suitable precision and accuracy but for detection only quantitation as an exact value is required. Limit of quantitation and limit of detection were calculated on the basis of standard deviation of the response and slope ${ }^{12}$. By applying formula, LOQ and LOD for chloramphenicol were calculated in the range of 36 and $11 \mathrm{ng} / \mathrm{mL}$, respectively. For prednisolone acetate, LOQ \& LOD were 31 and $10 \mathrm{ng} / \mathrm{mL}$, respectively.

Accuracy: Accuracy of both analytes was calculated and shown in Table-1. Accuracy of chloramphenicol was measured at three levels, $0.128,3.2,80 \mu \mathrm{g} / \mathrm{mL}$ and that of prednisolone

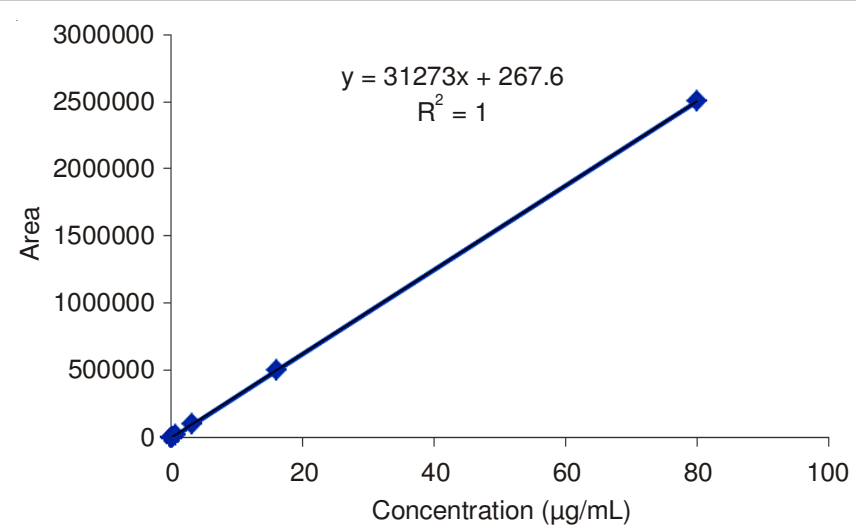

Fig. 9. Calibration curve of chloramphenicol

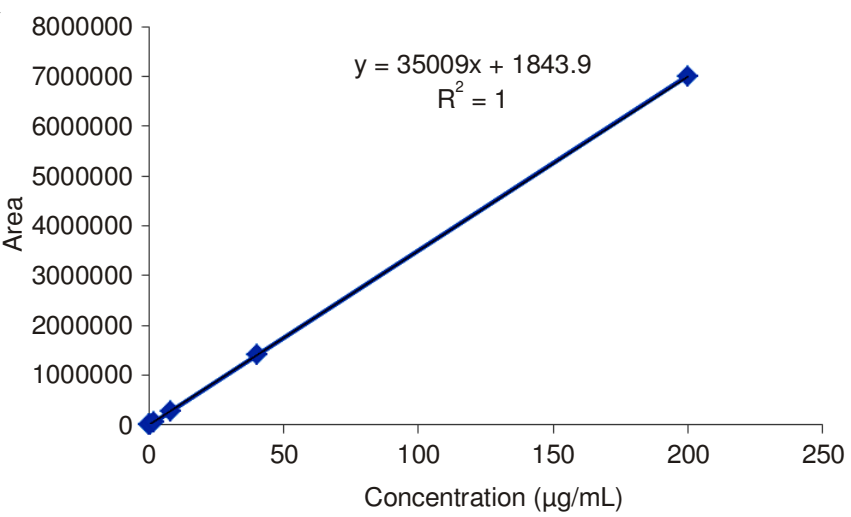

Fig. 10. Calibration curve of prednisolone Acetate

\begin{tabular}{ccccc}
\multicolumn{5}{c}{ TABLE-1 } \\
ACCURACY OF THE PROPOSED LC-DAD METHOD \\
\hline Drugs & $\begin{array}{c}\text { Conc. Spiked } \\
(\mu \mathrm{g} / \mathrm{mL})\end{array}$ & $\begin{array}{c}\text { Conc. detected } \\
(\mu \mathrm{g} / \mathrm{mL})\end{array}$ & $\begin{array}{c}\text { Accuracy } \\
(\%)\end{array}$ & $(\% \mathrm{RSD})$ \\
\hline \multirow{2}{*}{ Chloram- } & 80 & $79.86 \pm 0.999$ & 99.82 & 0.12 \\
phenicol & 3.2 & $3.199 \pm 0.0007$ & 99.97 & 0.02 \\
& 0.128 & $0.127 \pm 0.0007$ & 99.22 & 0.55 \\
\hline \multirow{2}{*}{ Prednisolone } & 200 & $199.5 \pm 0.354$ & 99.75 & 0.18 \\
acetate & 8.0 & $7.98 \pm 0.014$ & 99.75 & 0.17 \\
& 0.32 & $0.319 \pm 0.0007$ & 99.69 & 0.22 \\
\hline
\end{tabular}

acetate was at three different levels, 0.32, 8, $200 \mu \mathrm{g} / \mathrm{mL}$. Accuracy of the method was found to be well within specified limits. The percent RSD values did not exceed $1 \%$.

Precision of the method: The intra-day precision was demonstrated in terms of \% RSD of three different concentrations by injecting 6 replicate injections of each concentration on same day. The inter-day variability was examined on standard solution up to three concentration levels derived from linearity. \% RSD of three concentrations was calculated by injecting 9 replicate injections in 3 days (Table-2).

Robustness studies: Robustness of the method was studied by applying minor variations in the chromatographic conditions like composition of the mobile phase, flow rate, $\mathrm{pH}$ of the buffer solution and temperature. Chromatographic parameters such as number of theoretical plates, retention time, tailing factor and impacts on assay were studied ${ }^{14}$. Robustness study data of chloramphenicol and prednisolone acetate are presented in Tables 3 and 4, respectively. 


\begin{tabular}{|c|c|c|c|c|c|c|c|}
\hline \multicolumn{8}{|c|}{$\begin{array}{c}\text { TABLE-2 } \\
\text { RESULTS OF REPEATABILITY (INTRA-DAY) AND R }\end{array}$} \\
\hline \multirow[b]{2}{*}{ Drugs } & \multirow{2}{*}{$\begin{array}{l}\text { Conc. spiked } \\
(\mu \mathrm{g} / \mathrm{mL})\end{array}$} & \multicolumn{3}{|c|}{ Intra-day $(\mathrm{n}=6)$} & \multicolumn{3}{|c|}{ Inter-day $(\mathrm{n}=18)$} \\
\hline & & $\begin{array}{c}\text { Amount } \\
\text { quantitated }(\mu \mathrm{g} / \mathrm{mL})\end{array}$ & $\begin{array}{c}\mathrm{RSD} \\
(\%)\end{array}$ & $\begin{array}{l}\text { Accuracy } \\
(\%)\end{array}$ & $\begin{array}{c}\text { Amount } \\
\text { quantitated }(\mu \mathrm{g} / \mathrm{mL})\end{array}$ & $\begin{array}{l}\text { RSD } \\
(\%)\end{array}$ & $\begin{array}{l}\text { Accuracy } \\
(\%)\end{array}$ \\
\hline \multirow{3}{*}{ Chloramphenicol } & 0.128 & $0.126 \pm 0.0009$ & 0.714 & 98.44 & $0.125 \pm 0.001$ & 0.80 & 97.65 \\
\hline & 3.20 & $3.19 \pm 0.004$ & 0.125 & 99.69 & $3.19 \pm 0.003$ & 0.09 & 99.69 \\
\hline & 80.0 & $79.04 \pm 0.424$ & 0.536 & 98.81 & $78.87 \pm 0.399$ & 0.506 & 98.59 \\
\hline \multirow{3}{*}{ Prednisolone Acetate } & 0.320 & $0.317 \pm 0.001$ & 0.315 & 99.06 & $0.316 \pm 0.001$ & 0.316 & 98.75 \\
\hline & 8.0 & $7.95 \pm 0.022$ & 0.277 & 99.37 & $7.94 \pm 0.021$ & 0.264 & 99.3 \\
\hline & 200.0 & $199.23 \pm 0.344$ & 0.173 & 99.61 & $198.27 \pm 0.612$ & 0.309 & 99.13 \\
\hline
\end{tabular}

\begin{tabular}{|c|c|c|c|c|}
\hline \multicolumn{5}{|c|}{$\begin{array}{c}\text { TABLE-5 } \\
\text { SPECIFICITY OF THE METHOD }\end{array}$} \\
\hline Compounds & Nature of stress & $\mathrm{N}$ & \% Degradation & $\%$ Recovered \\
\hline \multirow{4}{*}{ Chloramphenicol } & $\operatorname{HCL}(2 \mathrm{M})$ for $20 \mathrm{~min}$ & 3 & 2.83 & 97.17 \\
\hline & $\mathrm{NaOH}(1.25 \mathrm{M})$ for $20 \mathrm{~min}$ & 3 & 1.17 & 98.83 \\
\hline & $\mathrm{KMNO}_{4}(0.006 \mathrm{M})$ for $30 \mathrm{~min}$ & 3 & 0.5 & 100.7 \\
\hline & Reflux at $120 \mathrm{C}$ for $2 \mathrm{~h}$ & 3 & 1.74 & 98.26 \\
\hline \multirow{4}{*}{ Prednisolone Acetate } & $\operatorname{HCL}(2 \mathrm{M})$ for $20 \mathrm{~min}$ & 3 & 15.57 & 84.43 \\
\hline & $\mathrm{NaOH}(1.25 \mathrm{M})$ for $20 \mathrm{~min}$ & 3 & 10.09 & 89.91 \\
\hline & $\mathrm{KMNO}_{4}(0.006 \mathrm{M})$ for $30 \mathrm{~min}$ & 3 & 14.74 & 85.26 \\
\hline & Reflux at $120^{\circ} \mathrm{C}$ for $2 \mathrm{~h}$ & 3 & 3.34 & 96.66 \\
\hline
\end{tabular}

\begin{tabular}{|c|c|c|c|c|}
\hline \multicolumn{5}{|c|}{$\begin{array}{c}\text { TABLE-3 } \\
\text { ROBUSTNESS STUDY OF CHLORAMPHENICOL }\end{array}$} \\
\hline $\begin{array}{l}\text { Chromatographic } \\
\text { conditions }\end{array}$ & $\begin{array}{l}\text { Retention } \\
\text { time }(\mathrm{Rt})\end{array}$ & $\begin{array}{l}\text { Tailing } \\
\text { factor }\end{array}$ & Theoretical & Assay \% \\
\hline Methanol: buffer (70:30) & 2.27 & 1.342 & 5220 & 99.58 \\
\hline Methanol buffer (68:32) & 2.348 & 1.313 & 4912 & 100.21 \\
\hline Methanol buffer (72:28) & 2.227 & 1.348 & 5051 & 100.57 \\
\hline Flow of rate $1.40 \mathrm{~mL} \mathrm{~min}^{-1}$ & 2.439 & 1.302 & 5020 & 101.05 \\
\hline Flow of rate $1.60 \mathrm{~mL} \mathrm{~min}^{-1}$ & 2.134 & 1.323 & 4967 & 98.93 \\
\hline Buffer $\mathrm{pH} 3$ & 2.239 & 1.33 & 4980 & 99.25 \\
\hline Buffer $\mathrm{pH} 3$ & 2.2 & 1.305 & 5021 & 99.69 \\
\hline Column oven $40^{\circ} \mathrm{C}$ & 2.205 & 1.335 & 5475 & 99.19 \\
\hline \multicolumn{5}{|c|}{$\begin{array}{c}\text { TABLE-4 } \\
\text { ROBUSTNESS STUDY OF PREDNISOLONE ACETATE }\end{array}$} \\
\hline Chromatographic conditions & $\begin{array}{l}\text { Retenion } \\
\text { time (Rt) }\end{array}$ & $\begin{array}{l}\text { Tailing } \\
\text { factor }\end{array}$ & Theoretical & $\begin{array}{l}\text { Assay } \\
(\%)\end{array}$ \\
\hline Methanol: buffer (70:30) & 3.659 & 1.201 & 6962 & 99.58 \\
\hline Methanol: buffer (68:32) & 4.002 & 1.164 & 6644 & 100.25 \\
\hline Methanol: buffer (72:28) & 3.331 & 1.193 & 6415 & 100.42 \\
\hline Flow of rate $1.40 \mathrm{~mL} \mathrm{~min}^{-1}$ & 3.844 & 1.169 & 6625 & 101.1 \\
\hline Flow of rate $1.60 \mathrm{~mL} \mathrm{~min}^{-1}$ & 3.322 & 1.179 & 6188 & 98.9 \\
\hline Buffer $\mathrm{pH} 3$ & 3.601 & 1.2 & 6580 & 99.93 \\
\hline Buffer $\mathrm{pH} 3$ & 3.663 & 1.251 & 6350 & 99.1 \\
\hline Column oven $40{ }^{\circ} \mathrm{C}$ & 3.301 & 1.19 & 6891 & 100.01 \\
\hline
\end{tabular}

Specificity of the method: Specificity of the method was done by performing degradation studies of both the analytics in their mixture form. For this purpose, the analytics were treated with acidic, basic, oxidative and thermal conditions. Chloramphenicol degraded $2.83 \%$ with acidic stress, $1.17 \%$ with basic stress $0.5 \%$ with oxidative stress and $1.74 \%$ with heat stress where as prednisolone acetate degraded $15.57 \%$ with acidic stress, $10.09 \%$ with basic stress, $14.75 \%$ with oxidative stress and $3.34 \%$ with heat stress (Table-5).

System suitability studies:

$$
\begin{gathered}
\text { Standard deviation }(\mathrm{S})=\sqrt{\frac{\sum(\mathrm{Xi}-\mathrm{X})^{2}}{\mathrm{n}-1}} \\
=\sqrt{\frac{409029923.200}{4}}
\end{gathered}
$$

$$
=10112.2441
$$

Relative standard deviation $(\mathrm{CV})=\frac{\mathrm{S} \times 100}{\mathrm{X}}$

$$
(C V)=\frac{10112.2441 \times 100}{2213024.600}
$$

$(\mathrm{CV})=0.46 \%$

\begin{tabular}{cccc}
\hline Sr. no. & $\mathrm{Xi}$ & $(\mathrm{Xi}-\mathrm{X})$ & $(\mathrm{Xi}-\mathrm{X})^{2}$ \\
\hline 1 & 2199618 & -13406.6 & 179736923.6 \\
2 & 2214670 & 1645.4 & 2707341.16 \\
3 & 2215800 & 2775.4 & 7702845.16 \\
4 & 2226965 & 13940.4 & 194334752.2 \\
5 & 2208070 & -4954.6 & 24548061.16 \\
$\mathrm{X}$ & 2213024.6 & & $\Sigma(\mathrm{Xi}-\mathrm{X})^{2}=409029923$ \\
\hline
\end{tabular}

\section{Conclusion}

A simple and reliable method was developed and validated for simultaneous determination of chloramphenicol, prednisolone acetate, excipients and degradation products. Developed method can be used confidently for routine quality control analysis of chloramphenicol and prednisolone acetate as raw active ingredients in eye drops.

\section{ACKNOWLEDGEMENTS}

The authors are grateful to The Principal, University College of Pharmacy for providing facilities to complete the required research work. Special thanks are also due to the Principal, Government College University, Lahore for the availability of chemicals.

\section{REFERENCES}

1. J.M.L. Gallego and J.P. Arroyo, J. Pharm. Biomed. Anal., 31, 873 (2003).

2. S.N. Razzaq, I.U. Khan, I. Mariam and S.S. Razzaq, Chem. Cent. J., 6, 94 (2012).

3. M. Diestelhorst, F. Aspacher, W. Konen, G. Krieglstein and R.D. Hilgers, Graef. Arch. Clin. Exp., 230, 451 (1992). 
4. L. Valvo, A. Paris, A. Savella, B. Gallinella and E.C. Signoretti, J. Pharm. Biomed. Anal., 12, 805 (1994).

5. S. Ahmed and M. Riaz, Chromatographia, 31, 67 (1991).

6. H. Ashwin, S. Stead, J. Taylor, J. Startin, S. Richmond, V. Homer, T. Bigwood and M. Sharman, Anal. Chim. Acta, 529, 103 (2005).

7. S.G. Musharraf, U. Fatima and R. Sultana, Chem. Cent. J., 6, 9 (2012),

8. H.T. Rønning, K. Einarsen and T.N. Asp, J. Chromatogr. A, 1118, 226 (2006).

9. M.E. Falagas, A.P. Grammatikos and A. Michalopoulos, Expert Rev. Anti Infect. Ther., 6, 593 (2008).
10. Y. Hongxin, Chinese Pharm. Affairs, 6, 410 (2007).

11. P. Katakam and K. Sireesha, Asian J. Pharm. Clin. Res., 5, 182 (2012).

12. D.A. Armbruster, M.D. Tillman and L.M. Hubbs, Clin. Chem., 40, 1233 (1994).

13. ICH Q2 (R1) Validation of Analytical Procedures: Text and Methodology, http://www.ich.org/fileadmin/Public_Web_Site/ICH_Products/Guidelines/Quality/Q2_R1/Step4/Q2_R1_Guideline.pdf (Accessed on 15 March 2014).

14. ICH Harmonised Tripartite Guideline, Validation of Analytical Procedures: Methodology, http://www.hc-sc.gc.ca/dhp-mps/alt_formats/hpfbdgpsa/pdf/prodpharma/q2b-eng.pdf (Accessed on 02 March 2014). 